\title{
Association between comorbidities and death from COVID-19 in different age groups
}

Pedro Emanuel Fleitas ${ }^{\mathrm{a}, \mathrm{b}^{*}}$, María Cristina Almazán ${ }^{\mathrm{a}, \mathrm{b}}$, Sabrina Daniela Cortez ${ }^{\mathrm{b}}$, Jorge Augusto

a. Instituto de Investigaciones de Enfermedades Tropicales (IIET-CONICET), Universidad Nacional de Salta. Alvarado 751. San Ramón de la Nueva Orán, Salta, Argentina. ZC: 4530 .

b. Cátedra de Química Biológica, Facultad de Ciencias Naturales, Universidad Nacional de Salta. Avenida Bolivia 5150. Salta, Argentina. ZC: 4400.

c. Instituto de Estudios Laborales y del Desarrollo Económico (IELDE), Consejo Nacional de Investigaciones Científicas y Técnicas (CONICET), Universidad Nacional de Salta. Avenida Bolivia 5150. Salta, Argentina. ZC: 4400.

* Corresponding autor: PhD. Pedro E. Fleitas

Mail: pedro.fleittas@gmail.com

Tel: +5493424408448

17 Work address: Instituto de Investigaciones de Enfermedades Tropicales (IIET). Alvarado 751, 
medRxiv preprint doi: https://doi.org/10.1101/2021.04.12.21255365; this version posted April 15, 2021. The copyright holder for this preprint (which was not certified by peer review) is the author/funder, who has granted medRxiv a license to display the preprint in perpetuity.

It is made available under a CC-BY-NC-ND 4.0 International license .

\section{Abstract}

21 Background: This new COVID-19 pandemic challenges health systems around the world;

22 therefore, it is extremely important to determine which patients with COVID-19 can evolve to

23 more severe outcomes. Accordingly, we decided to assess the role that comorbidities play in

24 death from COVID-19.

25 Methods: Two age groups ( $<60$ and $\geq 60$ years) were defined for analysis. Decision trees were

26 made to identify which comorbidities had the highest fatality rate (FR). Multiple logistic

27 regressions were performed to measure the association between comorbidities and death.

28 Results: A significant difference was found between the FR of $<60$ group and $\geq 60$ group. The

29 most frequent comorbidity were cardiac diseases and diabetes. The combination of comorbidities

30 with the highest FR was diabetes with kidney disease. Combinations of more than two

31 comorbidities presented higher FR. The comorbidities had higher Odd ratios in the younger

32 group than in the older group.

33 Conclusions: Comorbidities seem to play a greater role in death from COVID-19 in the younger

34 group, while in the $>60$ group; age seems to be the most important factor. We assigned a score to

35 the comorbidities and their combinations for both age groups to help the health personnel make

36 decisions.

37 Keywords

38 COVID-19; Comorbidities; Fatality rate; Score 
medRxiv preprint doi: https://doi.org/10.1101/2021.04.12.21255365; this version posted April 15, 2021. The copyright holder for this preprint (which was not certified by peer review) is the author/funder, who has granted medRxiv a license to display the preprint in perpetuity.

It is made available under a CC-BY-NC-ND 4.0 International license .

\section{Introduction}

41 From the first case of COVID-19 that was reported in the city of Wuhan, China in December

422019 until the beginning of November 2020, 46 million infected people have been reported

43 worldwide. ${ }^{1}$ Of these 46 million, $2.6 \%$ have died. ${ }^{1}$ This new pandemic challenges health systems

44 around the world and carries important ethical questions, especially under the need of rationing

45 health care in the context of scarce resources and crisis capacity. ${ }^{2}$ For this reason, it is extremely

46 important to determine which patients with COVID-19 can evolve to more severe outcomes,

47 including death. Age, male gender, and ethnicity have all been reported to be associated with

48 severe COVID-19 outcomes. ${ }^{3,4}$ Also, comorbidities such as diabetes, kidney, respiratory, and

49 cardiovascular diseases have been reported as risk factors for severe outcomes by COVID-19. ${ }^{3,5}$

50 Based on this, we decided to assess the role that comorbidities play in death from COVID-19 in a

51 large database from Brazil that includes recovered and deceased patients, to provide valuable

52 information for designing strategies for case management.

\section{Material and methods}

\section{Data source}

55 The data file was downloaded from the website of the Brazilian Ministry of Health on August 1,

56 2020. ${ }^{6}$ The data comes from the e-SUS NOTIFICA system, which was developed to register

57 suspected cases of COVID-19 in Brazil, and contains patient information such as place of

58 residence, clinical, demographic, and epidemiological characteristics. An ad-hoc database was

59 built for this project with all laboratory confirmed positive cases (RT-PCR or serology) or

60 clinical-epidemiological survey containing information on date of onset of symptoms, date of the 
medRxiv preprint doi: https://doi.org/10.1101/2021.04.12.21255365; this version posted April 15, 2021. The copyright holder for this preprint (which was not certified by peer review) is the author/funder, who has granted medRxiv a license to display the preprint in perpetuity.

It is made available under a CC-BY-NC-ND 4.0 International license .

61 diagnostic test, age, sex, and disease evolution. Patients with missing data were excluded from

62 the database. We did not impose any further exclusion criteria to limit selection bias.

\section{Study design}

64 Two age-group were defined for the analysis with those $<60$ or $\geq 60$ years-old. Decision trees

65 were built to order the comorbidities according to their frequency and the proportion of deaths

66 from COVID-19 reported. Then, the correlation of the absence/presence of the following

67 comorbidities: diabetes, immunosuppression, kidney, respiratory, and cardiovascular disease with

68 death from COVID-19 was analyzed. For this, a multiple logistic regression was performed to

69 identify which variables were associated with death from COVID-19. Also, the probability

70 obtained from logistic regressions (probability of dying when infected by COVID-19 if the

71 comorbidities were present) was used to calculate the area under the receiver-operator

72 characteristic curve (AUC). The AUC was used as a measure of the ability of the comorbidities

73 model to predict death from COVID-19. Finally, the values of probability obtained from logistic

74 regressions were used to assign a score to the comorbidities and the combinations of them. All

75 statistical analyses were carried with RStudio version 1.3.1093 (RStudio: Integrated

76 Development for R. RStudio, PBC, Boston, MA). Analyses with p-values <0.05 for a level of

77 significance of $95 \%$ were considered statistically significant. Figures were done with GraphPad

78 Prime 9 Trial version (GraphPad Software Inc., San Diego, CA).

\section{Results}

\section{Data description}

81 The whole database includes over 8 million cases recorded in the 27 states of Brazil from January

821 to August 1 2020, 549733 were included in the analysis (Fig. 1). A summary of the 
medRxiv preprint doi: https://doi.org/10.1101/2021.04.12.21255365; this version posted April 15, 2021. The copyright holder for this preprint (which was not certified by peer review) is the author/funder, who has granted medRxiv a license to display the preprint in perpetuity. It is made available under a CC-BY-NC-ND 4.0 International license .

83 comorbidities registered in all the patients can be observed in Table S1 of supplementary 84 material. In our database, median age was 38 years old (IQR: 30-51); 46\% were males and 54\% 85 females. It was found that $2.1 \%$ of patients died while $97.9 \%$ were recovered. A statistically 86 significant difference was found between the fatality rate of $<60$ group $(0.7 \%, \mathrm{n}=457557)$ and $\geq$ 8760 group $(11.3 \% \mathrm{n}=74176)(\mathrm{p}<0.01)($ Fig. 2$)$. Also, the median time between the onset of 88 symptoms and death was 20 days (IQR: 12-33), and no differences were found between age 89 groups.

90 Five comorbidities were recorded in the data file: cardiovascular disease, immunosuppression, 91 kidney disease, respiratory disease, and diabetes. Among $87.6 \%$ of the cases, no comorbidities 92 were registered; meanwhile, the most frequent comorbidity registered in the database was 93 cardiovascular disease (7.2\% (39542/549733)), followed by diabetes $(4.3 \%(23966 / 549733))$, 94 respiratory disease $(2.0 \%(11035 / 549733))$, immunosuppression $(0.9 \%(4934 / 549733))$ and 95 kidney disease $(0.5 \%(2684 / 549733))$. In addition, It was observed that in the <60 group, cardiac 96 disease $($ Frequency $=4.3 \%)$ and diabetes $($ Frequency $=2.6 \%)$ presented a fatality rate of $1.6 \%$ and $970.5 \%$ (Fig. 3a). In addition, the highest fatality rate (19\%) was found in individuals with diabetes 98 and kidney disease (Fig. 3a). In the $\geq 60$ group the most frequent comorbidities were also diabetes 99 (Frequency $=15 \%$, fatality rate $=19 \%$ ) and cardiovascular disease, without diabetes, (Frequency $100=12.4 \%$, fatality rate $=13 \%$ ). At the same time, the combination of comorbidities with the highest 101 fatality rate was diabetes with kidney disease (fatality rate $=35 \%$ ) and diabetes with kidney and 102 respiratory diseases (fatality rate $=47 \%$ ) (Fig. 3b). 
medRxiv preprint doi: https://doi.org/10.1101/2021.04.12.21255365; this version posted April 15, 2021. The copyright holder for this preprint (which was not certified by peer review) is the author/funder, who has granted medRxiv a license to display the preprint in perpetuity.

It is made available under a CC-BY-NC-ND 4.0 International license .

105

106

107

108

109

110

111

112

113

114

115

116

117

118

119

120

121

122

123

124

Figure 1: Flowchart of data used in this study. *According to Guidelines for Case Notification of Influenza Syndrome suspected of COVID-19. ${ }^{7}$

Figure 2: Frequency of recovery and death from COVID-19, according to the patient's age.

Figure 3: Tree diagrams representing the frequency of the comorbidities and the fatality rate. a. $<60$ group ( $n=457557)$. b. $\geq 60$ group $(n=74176)$. In each node, its number is represented in the top, and inside the fatality rate $(\mathrm{MR})$ and the percentage frequency $(\mathrm{F}) . \mathrm{DBT}=$ Diabetes, $\mathrm{IS}=$ immunosuppression, $\mathrm{KD}=$ kidney disease, $\mathrm{RD}=$ respiratory disease, $\mathrm{CD}=$ Cardiovascular disease, $\mathrm{P}=$ comorbidity present and $\mathrm{A}=$ comorbidity absent.

\section{Correlation among comorbidities and death from COVID-19}

For the $<60$ group and $\geq 60$ groups, the values of $\mathrm{AUC}=0.66$ and $\mathrm{AUC}=0.61$ were obtained, respectively. As Fig. 4 shows, the comorbidities had higher ORs in the $<60$ group than in the $\geq$ 60 group. In this first group, diabetes, kidney disease, and immunosuppression had the highest ORs; whereas in the $\geq 60$ group, the comorbidities with the highest ORs were kidney and respiratory diseases (Fig. 4).

The logistic regression allowed us to assign a score to the comorbidities and their combinations, from one (lower probability of a severe outcome) to eight (high probability of a severe outcome) for both age groups. These scores were ordered into three categories of low, medium, and high risk, based on the incidence of death from COVID-19. It can be observed that the highest score is 
medRxiv preprint doi: https://doi.org/10.1101/2021.04.12.21255365; this version posted April 15, 2021. The copyright holder for this preprint (which was not certified by peer review) is the author/funder, who has granted medRxiv a license to display the preprint in perpetuity.

It is made available under a CC-BY-NC-ND 4.0 International license .

125 found with the combination of diabetes and kidney disease or the combination of 3 or more

126 comorbidities.

127 Figure 4: Odds ratios for comorbidities in the $<60$ group and $\geq 60$ age group.

Table 1: Score assigned to the different comorbidities based on the probability of death when infected by COVID-19 (multivariate logistic regression) and the fatality rate.

\begin{tabular}{|c|c|c|c|}
\hline \multicolumn{4}{|l|}{$<60$ group } \\
\hline \multicolumn{2}{|l|}{ Score range } & \multirow{2}{*}{$\begin{array}{l}\text { Comorbidities } \\
\text { Cardiovascular disease }\end{array}$} & \multirow{2}{*}{$\begin{array}{l}\text { Assigned score } \\
1\end{array}$} \\
\hline Low Score & Probability & & \\
\hline & $\begin{array}{l}\text { Fatality rate } \\
=0.5 \\
n=458076\end{array}$ & Respiratory disease & 1 \\
\hline \multirow[t]{4}{*}{$\begin{array}{l}\text { Medium } \\
\text { Score }\end{array}$} & \multirow{4}{*}{$\begin{array}{l}\text { Probability } \\
=0.02-0.04 \\
\text { Fatality rate } \\
=4.0 \\
n=12352\end{array}$} & $\begin{array}{l}\text { Cardiovascular disease + } \\
\text { Respiratory disease }\end{array}$ & 2 \\
\hline & & Immunosuppression & 2.5 \\
\hline & & Kidney disease & 3 \\
\hline & & Diabetes & 3.5 \\
\hline \multirow[t]{4}{*}{ High Score } & \multirow{4}{*}{$\begin{array}{l}\text { Probability } \\
\geq 0.05 \\
\text { Fatality rate } \\
=7.0 \\
n=5129\end{array}$} & $\begin{array}{l}\text { Immunosuppression + } \\
\text { Respiratory disease }\end{array}$ & 4 \\
\hline & & $\begin{array}{l}\text { Kidney disease + Respiratory } \\
\text { disease }\end{array}$ & 5 \\
\hline & & $\begin{array}{l}\text { Diabetes + Respiratory } \\
\text { disease }\end{array}$ & 5.5 \\
\hline & & $\begin{array}{l}\text { Immunosuppression + } \\
\text { Cardiovascular disease }\end{array}$ & 6 \\
\hline
\end{tabular}


medRxiv preprint doi: https://doi.org/10.1101/2021.04.12.21255365; this version posted April 15, 2021. The copyright holder for this preprint (which was not certified by peer review) is the author/funder, who has granted medRxiv a license to display the preprint in perpetuity.

It is made available under a CC-BY-NC-ND 4.0 International license .

131

\begin{tabular}{|l|l|l|}
\hline \multirow{n}{*}{} & $\begin{array}{l}\text { Cardiovascular disease + } \\
\text { Renal disease }\end{array}$ & 6.5 \\
\cline { 2 - 3 } & $\begin{array}{l}\text { Diabetes + cardiovascular } \\
\text { disease }\end{array}$ & 7 \\
\cline { 2 - 4 } & $\begin{array}{l}\text { Immunosuppression + Kidney } \\
\text { disease }\end{array}$ & 7.5 \\
\hline & $\begin{array}{l}\text { Diabetes + Kidney disease or } \geq \\
\text { 3 comorbidities }\end{array}$ & 8 \\
\hline
\end{tabular}

\begin{tabular}{|c|c|c|c|}
\hline \multicolumn{4}{|c|}{$\geq 60$ group } \\
\hline \multicolumn{2}{|c|}{ Score range } & Comorbidities & \multirow{2}{*}{$\begin{array}{l}\text { Assigned score } \\
1 \\
\end{array}$} \\
\hline \multirow{3}{*}{$\begin{array}{l}\text { Low } \\
\text { Score }\end{array}$} & \multirow{3}{*}{$\begin{array}{l}\text { Probability }<0.17 \\
\text { Fatality rate }=9.9 \\
n=65466\end{array}$} & Cardiovascular disease & \\
\hline & & Immunosuppression & 1 \\
\hline & & Diabetes & 1 \\
\hline \multirow{10}{*}{$\begin{array}{l}\text { Medium } \\
\text { Score }\end{array}$} & \multirow{10}{*}{$\begin{array}{l}\text { Probability } 0.17- \\
0.29 \\
\text { Fatality rate= } \\
20.7 \\
n=7801\end{array}$} & Respiratory disease & 2 \\
\hline & & $\begin{array}{l}\text { Immunosuppression } \\
\text { Cardiovascular disease }\end{array}$ & 2.5 \\
\hline & & Kidney disease & 3 \\
\hline & & $\begin{array}{l}\text { Cardiovascular disease }+ \\
\text { diabetes }\end{array}$ & 3.5 \\
\hline & & $\begin{array}{l}\text { Diabetes } \\
\text { Immunosuppression }\end{array}$ & 4 \\
\hline & & $\begin{array}{l}\text { Cardiovascular disease }+ \\
\text { Respiratory disease }\end{array}$ & 4.5 \\
\hline & & $\begin{array}{l}\text { Immunosuppression } \\
\text { Respiratory disease }\end{array}$ & 5 \\
\hline & & $\begin{array}{l}\text { Cardiovascular } \quad \text { disease } \quad+ \\
\text { Kidney disease }\end{array}$ & 5.5 \\
\hline & & $\begin{array}{l}\text { Diabetes }+ \text { Respiratory } \\
\text { disease }\end{array}$ & 6 \\
\hline & & Immunosuppression + Kidney & 6.5 \\
\hline
\end{tabular}


medRxiv preprint doi: https://doi.org/10.1101/2021.04.12.21255365; this version posted April 15, 2021. The copyright holder for this preprint (which was not certified by peer review) is the author/funder, who has granted medRxiv a license to display the preprint in perpetuity.

It is made available under a CC-BY-NC-ND 4.0 International license .

\begin{tabular}{|l|l|l|l|}
\hline & & disease & \\
\hline High & Probability $\geq 0.29$ & $\begin{array}{l}\text { Renal disease + Respiratory } \\
\text { Score }\end{array}$ & 7 \\
& Fatality rate $=$ & 7 & \\
\cline { 3 - 3 } & $\mathrm{n}=909$ & $\begin{array}{l}\text { Diabetes + Kidney disease or } \geq \\
\text { 3 comorbidities }\end{array}$ & 8 \\
& & & \\
\cline { 3 - 4 } & & & \\
\hline
\end{tabular}

135 Since the beginning of the COVID-19 pandemic in December 2019, the reported case fatality rate 136 has varied. Early estimates from small cohorts of hospitalized patients indicated a fatality rate of $13715 \%$; later and with more data, the percentage of deaths fell from $11 \%$ to $4.3 \%$ and finally to $1383.4 \% .^{8}$ In addition, $81 \%$ of patients with COVID-19 have a mild illness and never require 139 hospitalization. ${ }^{9}$ Therefore, for a better understanding of the causes that lead to severe results of 140 COVID-19, in this retrospective cohort study, we analyzed risk factors for death in individuals 141 with COVID-19 in a large database from Brazil with a fatality rate of $2.1 \%$.

142 Older age has been reported by several authors as an important factor associated with the severity 143 of the disease or fatality in patients with COVID-19. ${ }^{4,510}$ In accordance with this, we found a 144 higher fatality rate in patients older than 60 years of age.

145 It is important to highlight the relevance of age-stratified analyses when examining the 146 association between comorbidities and fatality with COVID-19. ${ }^{5}$ In our study, the odd ratio (OR) 147 values for comorbidities varied depending on age group. In the <60 group, both higher ORs and a 148 higher AUC value were observed compared to those obtained for the $\geq 60$ group. This suggests 
medRxiv preprint doi: https://doi.org/10.1101/2021.04.12.21255365; this version posted April 15, 2021. The copyright holder for this preprint (which was not certified by peer review) is the author/funder, who has granted medRxiv a license to display the preprint in perpetuity. It is made available under a CC-BY-NC-ND 4.0 International license.

149

that the comorbidities considered are able to better explain the fatality from COVID-19 in the $<60$ group than in the $\geq 60$ group. Therefore, the comorbidities seem to have an important impact on death in the $<60$ group, while in the $\geq 60$ group the comorbidities might play a minor role in death from COVID-19. This suggests that the main risk factor in the older group is age itself, which is consistent with previous findings for Brazilians patients. ${ }^{3}$

Diabetes was the most frequent comorbidity and had the highest OR value in the $<60$. Patients who presented diabetes as comorbidity, reached a fatality rate of $0.5 \%$ and $19 \%$ in the $<60$ group and $\geq 60$ group, respectively (Fig. 2). Worth mentioning, Brazil is one of the countries with more diabetes cases in the world, being the estimated prevalence of $11.9 \%$ (95\% CI 7.7-17.8). ${ }^{11}$ The evolution of COVID-19 has shown to be more severe in patients with diabetes and metabolic dysfunction. $^{12}$ Recent data suggests that COVID-19 could precipitate acute metabolic complications of diabetes, such as diabetic ketoacidosis and hyperglycemia. The potential mechanisms that may increase susceptibility to severe COVID-19 in patients with diabetes include: 1) higher affinity cell binding and effective entry of the virus, 2) decreased viral clearance, 3) decreased $\mathrm{T}$ cell function, 4) increased susceptibility to hyperinflammation and cytokine storm syndrome, and 5) presence of cardiovascular diseases. ${ }^{13}$ This becomes more relevant when considering that the most frequent combination of comorbidities included diabetes and cardiovascular disease, with a fatality rate of $6 \%$ and $20 \%$ in the $<60$ group and $\geq 60$ group, respectively.

Another important risk factor is kidney disease. In the $\geq 60$ group, this comorbidity together with respiratory disease presented the highest ORs. Moreover, the combination of diabetes with kidney disease caused the highest fatality rates. Since diabetes is the main cause of chronic kidney disease, ${ }^{14}$ patients with these two comorbidities can represent diabetic patients in a more 
medRxiv preprint doi: https://doi.org/10.1101/2021.04.12.21255365; this version posted April 15, 2021. The copyright holder for this preprint (which was not certified by peer review) is the author/funder, who has granted medRxiv a license to display the preprint in perpetuity. It is made available under a CC-BY-NC-ND 4.0 International license .

172 severe stage of the disease or without adequate medical care. Interestingly, the human kidney has

173 been reported to be a target for SARS-CoV-2 $2^{15}$; however, it remains controversial whether

174 SARS-CoV-2 causes acute kidney injury. ${ }^{16}$

175 There is a wide spectrum of immunosuppressed patients, including patients with cancer, solid 176 organ transplant recipients, those taking antirheumatic drugs, primary immunodeficiency, and

177 HIV infection. We found that in both age groups, immunosuppression was a risk factor 178 associated with death from COVID-19. However, this should be interpreted with caution since 179 the database did not allow to determine precisely the underlying cause of the immunosuppression 180 and because there is controversy about the role immunosuppression in COVID-19. Previous 181 research indicates that patients with cancer and solid organ transplant recipients may have a 182 higher risk of developing more severe COVID-19. ${ }^{17,18}$ Nonetheless, immunosuppressed adults 183 with no further comorbidities might not be likely to have a severe clinical outcome. ${ }^{18}$ This 184 contradiction may be because the host's immune response is an important factor contributing to 185 the severity of COVID-19, through a dysregulation of innate immunity or an excessive 186 inflammatory response. ${ }^{19}$ Thus, immunosuppression, as a sole comorbidity, probably does not 187 determine a severe outcome.

188 As has been shown in this study, there are comorbidities that increase the probability of severe 189 COVID-19. Therefore, they should be considered in case management. Concerning this, we 190 assigned a score to each comorbidity to provide a possible order of priority. Based on the analysis 191 of this large database, there are small subgroups of cases that carry an exceedingly high risk of 192 death due to COVID-19. 
medRxiv preprint doi: https://doi.org/10.1101/2021.04.12.21255365; this version posted April 15, 2021. The copyright holder for this preprint (which was not certified by peer review) is the author/funder, who has granted medRxiv a license to display the preprint in perpetuity.

It is made available under a CC-BY-NC-ND 4.0 International license .

It is important to understand the limitations of this study when interpreting these results. First, possible selection biases cannot be ruled out due to the reduction of the data file. Second, the data come from all the states of Brazil, but might not be representative of the entire population, and the generalizability of the results beyond this cohort is unclear. However, it is worth noting the high number of cases analyzed and that the proportion of the comorbidities in the database $(n=549733)$ is similar to in the original data file $(n=8056794)$.

In conclusion, we demonstrate that diabetes, kidney disease, respiratory disease, cardiovascular disease, and immunosuppression are risk factors related to death from COVID-19, where age seems to be a determining factor. The combination of comorbidities increases the risk, which must be considered and analyzed for clinical decisions.

Competing interests: The authors declare that they have no competing interests.

Funding: This article did not have any kind of funding.

Ethics approval: The material used was freely available on the website of the Brazilian Ministry of Public Health, so it was not necessary to have ethical approval.

Supplementary materials: Supplementary material associated with this article can be found in the online version.

\section{References}

1. Hopkins C for SS and E (CSSE) J. COVID-19 Map - Johns Hopkins Coronavirus Resource Center. Accessed May 5, 2020. https://coronavirus.jhu.edu/map.html

2. Curtis JR, Kross E, Stapleton R. The Importance ofAddressing Advance Care Planning and Decisions About Do-Not-Resuscitate Orders During Novel Coronavirus 2019 (COVID-19). JAMA. 2020;346(323):1771-1772. doi:10.1056/nejmsa012528.

3. Baqui P, Bica I, Marra V, Ercole A, van der Schaar M. Ethnic and regional variations in hospital mortality from COVID-19 in Brazil: a cross-sectional observational study. Lancet 
medRxiv preprint doi: https://doi.org/10.1101/2021.04.12.21255365; this version posted April 15, 2021. The copyright holder for this preprint (which was not certified by peer review) is the author/funder, who has granted medRxiv a license to display the preprint in perpetuity. It is made available under a CC-BY-NC-ND 4.0 International license .

Glob Heal. 2020;8(8):e1018-e1026. doi:10.1016/S2214-109X(20)30285-0.

4. Zhou F, Yu T, Du R, Fan G, Liu Y, Liu Z, Xiang J, Wang Y, Song B, Gu X, Guan L, Wei Y, Li H, Wu X, Xu J, Tu S, Zhang Y, Chen H, Cao B. Clinical course and risk factors for mortality of adult inpatients with COVID-19 in Wuhan, China: a retrospective cohort study. Lancet. 2020;395(10229):1054-1062. doi:10.1016/S0140-6736(20)30566-3.

5. Harrison SL, Fazio-Eynullayeva E, Lane DA, Underhill P, Lip GYH. Comorbidities associated with mortality in 31,461 adults with COVID-19 in the United States: A federated electronic medical record analysis. PLoS Med. 2020;17(9):1-11. doi:10.1371/JOURNAL.PMED.1003321.

6. Notificações de Síndrome Gripal - Conjuntos de dados - Open Data. Accessed August 1, 2020. https://opendatasus.saude.gov.br/dataset/casos-nacionais

7. MINISTÉRIO DA SAÚDE Guia de ViGilância EpidemiolóGica EmerGência de Saúde Pública de Importância Nacional Pela Doença Pelo CoronaVíruS 2019. Accessed November 6, 2020. http://www.saude.gov.br/svs

8. Rajgor DD, Lee MH, Archuleta S, Bagdasarian N, Quek SC. The many estimates of the COVID-19 case fatality rate. Lancet Infect Dis. 2020;20(7):776-777. doi:10.1016/S14733099(20)30244-9.

9. Weiss P, Murdoch DR. Clinical course and mortality risk of severe COVID-19. Lancet. 2020;395(10229):1014-1015. doi:10.1016/S0140-6736(20)30633-4.

10. Verity R, Okell LC, Dorigatti I, Winskill P, Whittaker C, Imai N, Cuomo-Dannenburg G, Thompson H, Walker PGT, Fu H, Dighe A, Griffin JT, Baguelin M, Bhatia S, Boonyasiri A, Cori A, Cucunubá Z, FitzJohn R, Gaythorpe K, Green W, Hamlet A, Hinsley W, Laydon D, Nedjati-Gilani G, Riley S, van Elsland S, Volz E, Wang H, Wang Y, Xi X, Donnelly CA, Ghani AC, Ferguson NM. Estimates of the severity of coronavirus disease 2019: a model-based analysis. Lancet Infect Dis. 2020;20(6):669-677. doi:10.1016/S14733099(20)30243-7.

11. Telo GH, Cureau FV, De Souza MS, Andrade TS, Copês F, Schaan BD. Prevalence of diabetes in Brazil over time: A systematic review with meta-analysis. Diabetol Metab Syndr. 2016;8(1):1-13. doi:10.1186/s13098-016-0181-1.

12. The Lancet Diabetes \& Endocrinology. COVID-19 and diabetes: a co-conspiracy? Lancet Diabetes Endocrinol. 2020;8(October):801.

13. Muniyappa R, Gubbi S. COVID-19 pandemic, coronaviruses, and diabetes mellitus. Am J Physiol - Endocrinol Metab. 2020;318(5):E736-E741. doi:10.1152/ajpendo.00124.2020.

14. Pyram R, Kansara A, Banerji MA, Loney-Hutchinson L. Chronic kidney disease and diabetes. Maturitas. 2012;71(2):94-103. doi:10.1016/j.maturitas.2011.11.009.

15. Diao B, Wang C, Wang R, Feng Z, Tan Y, Wang H, Wang C, Liu L, Liu Y, Liu Y, Wang G, Yuan Z, Ren L, Wu Y, Chen Y. Human Kidney is a Target for Novel Severe Acute Respiratory Syndrome Coronavirus 2 ( SARS-CoV-2 ) Infection. Publ Online. 2020.

16. Zhou H, Zhang Z, Fan H, Li J, Li M, Dong Y, Guo W, Lin L, Kang Z, Yu T, Tian C, Gui 
medRxiv preprint doi: https://doi.org/10.1101/2021.04.12.21255365; this version posted April 15, 2021. The copyright holder for this preprint (which was not certified by peer review) is the author/funder, who has granted medRxiv a license to display the preprint in perpetuity. It is made available under a CC-BY-NC-ND 4.0 International license.

Y, Qin R, Wang H, Luo S, Hu D. Urinalysis, but not blood biochemistry, detects the early renal-impairment in patients with COVID-19. SSRN Electron J. 2020. doi:10.1101/2020.04.03.20051722.

17. Fung M, Babik JM. COVID-19 in Immunocompromised Hosts: What We Know So Far. Clin Infect Dis. 2020. doi:10.1093/cid/ciaa863.

18. Minotti C, Tirelli F, Barbieri E, Giaquinto C, Donà D. How is immunosuppressive status affecting children and adults in SARS-CoV-2 infection? A systematic review. J Infect. 2020;81(1):e61-e66. doi:10.1016/j.jinf.2020.04.026.

19. Abdulamir AS, Hafidh RR. The possible immunological pathways for the variable immunopathogenesis of COVID-19 infections among healthy adults, elderly and children. Electron J Gen Med. 2020;17(4):1-4. doi:10.29333/ejgm/7850. 


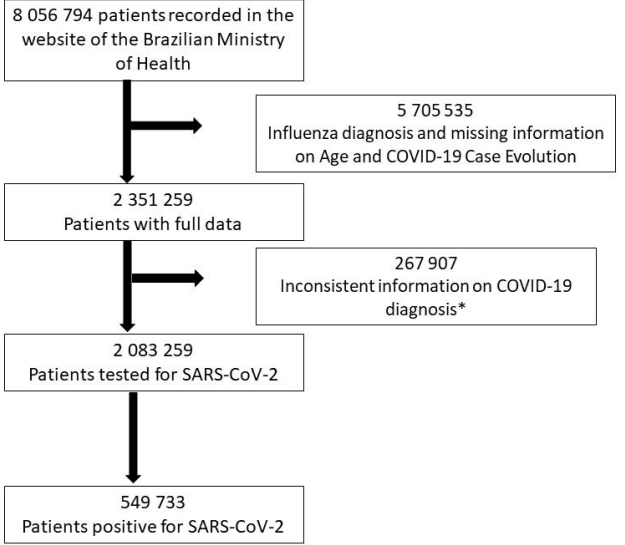


- Death

- Recovery

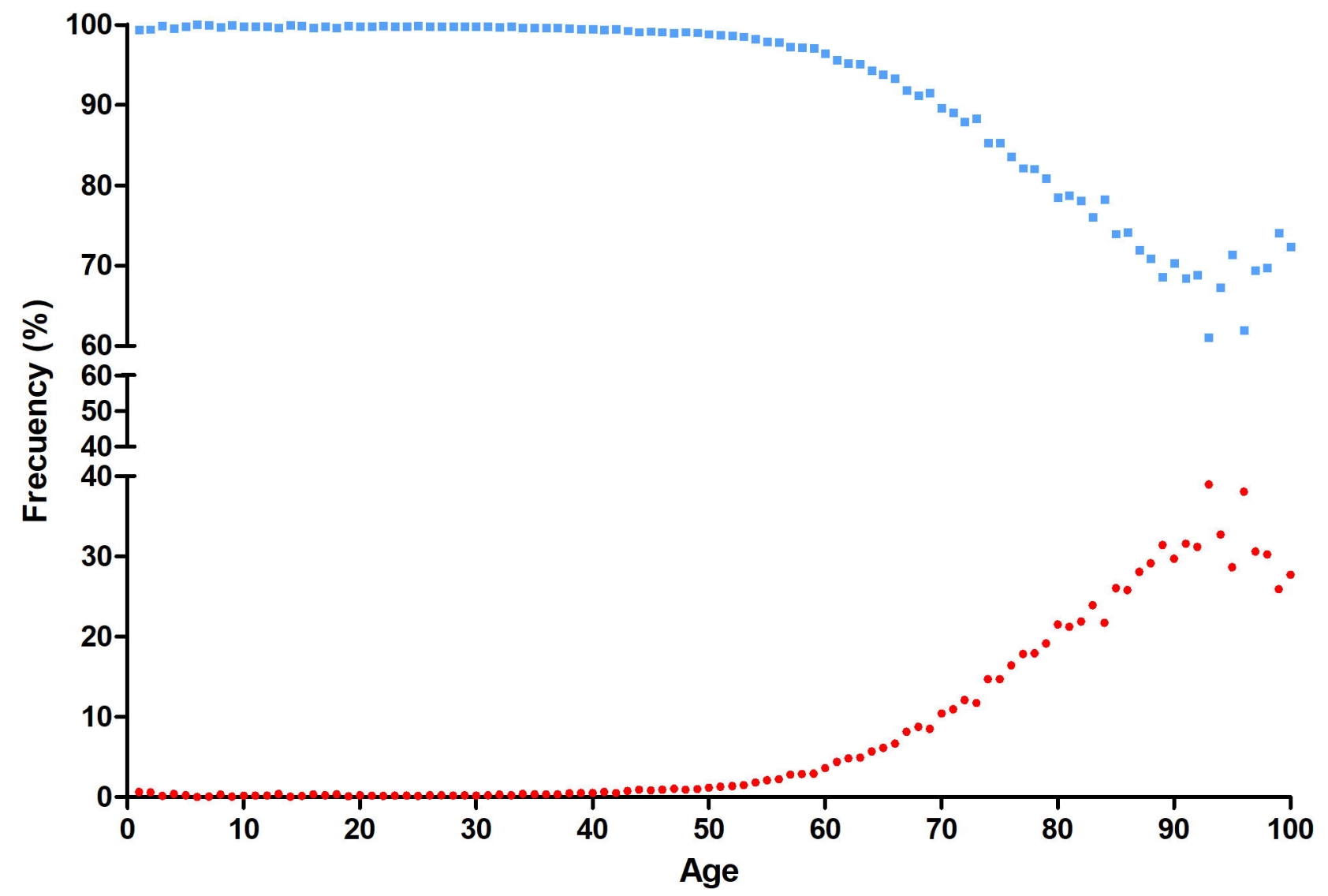



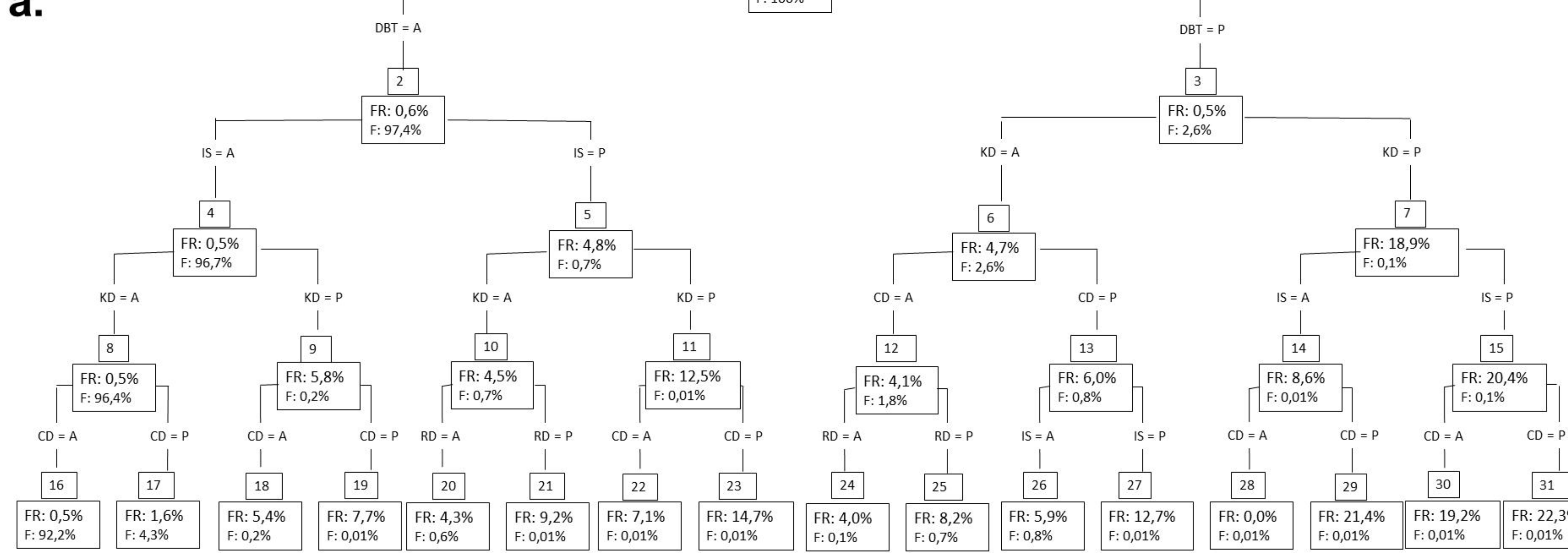
b.

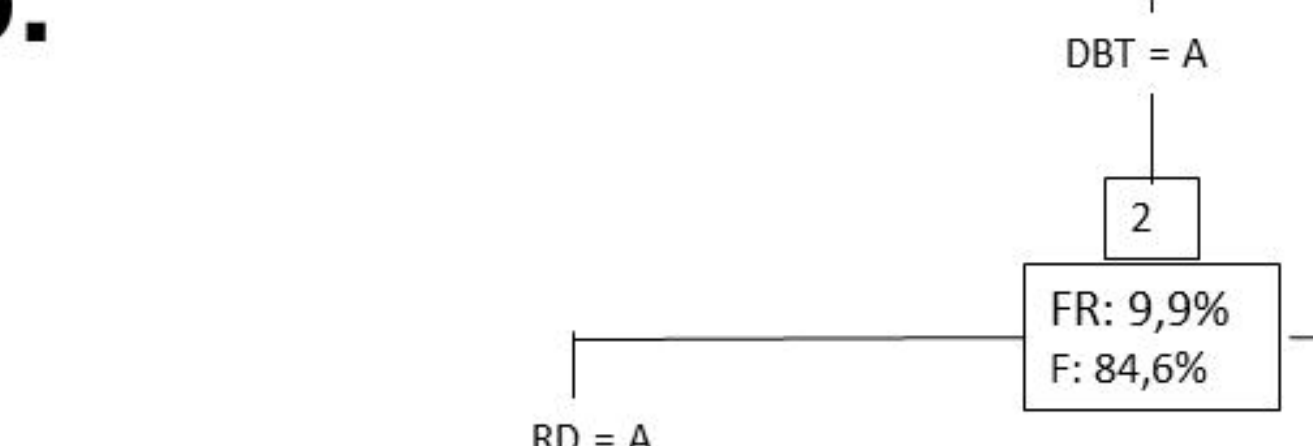

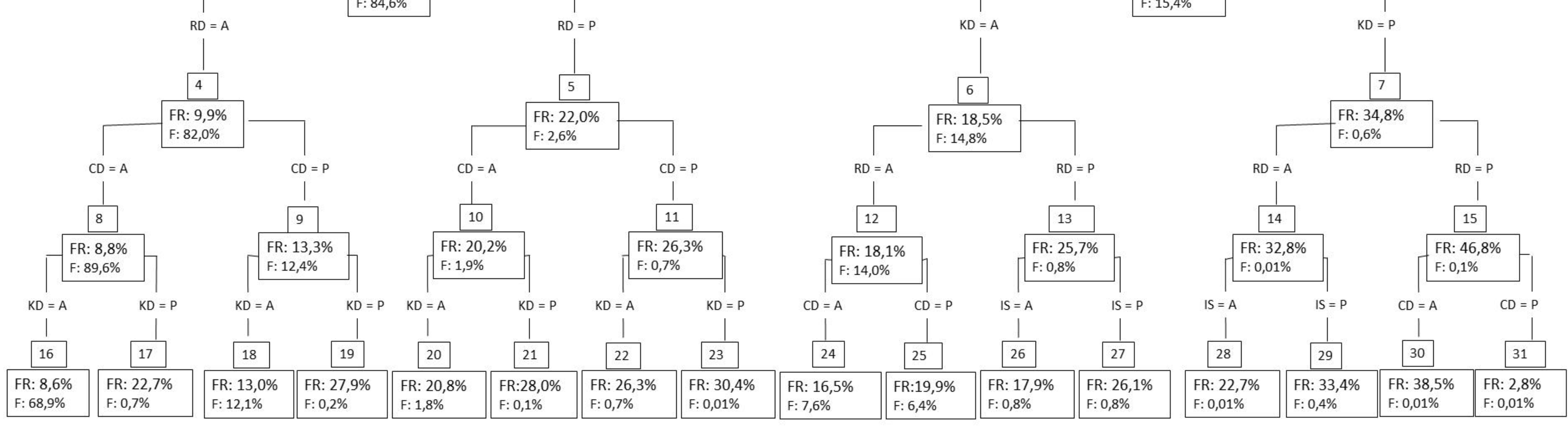


$>=60$ years old

- >60 years old

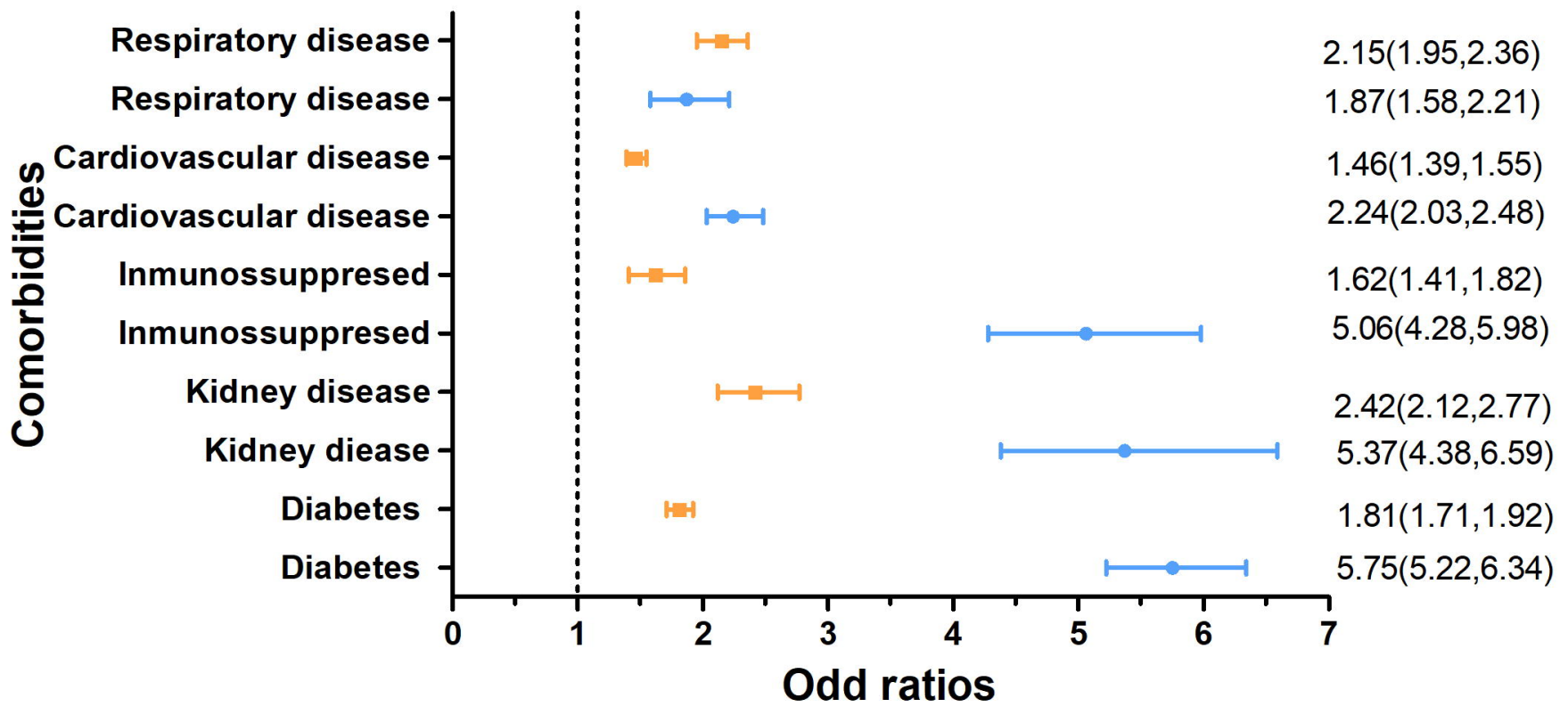

